\begin{tabular}{|c|c|c|}
\hline $\begin{array}{l}\text { EXCELLENT } \\
\text { PUBLISHERS }\end{array}$ & $\begin{array}{l}\text { International Journal of Current Research } \\
\text { and Academic Review } \\
\text { ISSN: 2347-3215 (Online):,; Volume } 5 \text { :,; Number } 10 \text { (October-2017) } \\
\text { Journal homepage: http://www.ijcrar.com }\end{array}$ & 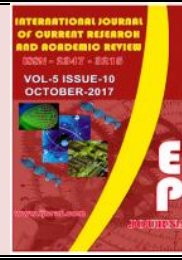 \\
\hline
\end{tabular}

doi: https://doi.org/10.20546/ijcrar.2017.510.006

\title{
Spatial and Seasonal Distribution of Endomycorrhiza from Cashew Nut in Bali
}

\author{
Meitini Wahyuni Proborini ${ }^{1 *}$, Deny Suhernawan Yusup ${ }^{1}$, Yan Ramona ${ }^{1}$ and Ni Putu Ristiati ${ }^{2}$ \\ ${ }^{I}$ Departement of Biology, Faculty of Math and Natural Science, University of Udayana, Bali \\ ${ }^{2}$ Department of Biology, University of Education, Ganesha, Singaraja (Undiksa), Bali
}

*Corresponding author

\begin{abstract}
Plants growing in poor soil areas are commonly associated with endomycorrhizalfungi as a mutualism symbiotic. The fungus takes a role on enhancement water from the soil and uptake soil mineral particularly Phosphorus, Magnesium and Potassium. Poor soil conditions at Bali Island are spatially located at Gerokgak-Buleleng Suburb (Northwest of Bali) and Sukadana-Karangasem Suburb (North-East of Bali). One of the economical plants growing well at the regions is cashew nut plant. However, less study on the endomycorrizhal fungi associated with cashew nut plat has been undertaken. The objective of this study is to observe the spatial and temporal variation of VAM presence at the cashew nut planting area, consisting of number of spores and percentage of infection (colonization) at Cashew nut plant root. The number of spores was counted by wet sieving and decanting methods and the root infection were observed by means of Grid-line Intersect method. The result showed that the cashew nut plant at both regions live symbiotic mutually with VAM. The VAM spore density in cashew nut rizhospher shows either temporal or spatial variation. The spore density in Rizhospher tend to increase over dry season (June up to December) and decrease over raining season (April up to June and December up to February). The spore density is considerably higher in rizhosphere at Sukadana region than those at Gerokgak region. Such spatial variation seems likely related to the soil properties. The VAM colonization was found as vesicle, urbuscle, internal-external hyphae and spore forms. The VAM colonization shows similar temporal variation at both areas, it is considerably related to the temporal variation of rain fall level. Percentage of VAM colonization over raining season (April up to June and December up to February) is higher than over dry season (June up to December). Such VAM colonization, nevertheless, does not show spatial variation.
\end{abstract}

\section{Article Info}

Accepted: 04 September 2017

Available Online: 20 October 2017

\section{Keywords}

Rhizosphere,

Colonization,

Spore density,

Poor soil

\section{Introduction}

Endomycorrhiza is an order of Fungi that lives in close association with higher plants, providing them with additional nutrients such as Phosphorous and Nitrogen (Smith et al., 2010). Especially the Arbuscular Mycorrhizal Fungi (AMF or VAM) are classical symbiotic mutualists between soil fungi and the absorbing organs of the vascular plants, in the benefit of both sides through the reciprocal exchange of minerals and organic resources (Johnson et al., 1997, Smith and Read 1997, Brundrett et al., 2008). Because of these benefits, over $70 \%$ of the vascular plants (Angiosperms and Gymnosperms) are living associated with 
mycorrhizal fungi (Deacon, 1997). Over 13 species and 4 Families of mycorrhiza have been discovered to date (Proborini et al., 2013).AMF take a significant role in some aspects of plant survival in arid regions, promoting plant growth and increasing plant productivity (Delvian, 2008; Proborini, 2011). Consequently, they play an important role in maintaining the ecosystem processes by promoting plant fitness through a range of mechanisms (Brundrett et al.,2008), e.g. protecting the host plants from soil pathogens (Smith, 2000) and improving texture and structure of soil, enhancing water and nutrient uptake (Smith et al., 2010). On the other hand, the species distribution of mycorrhiza depends on the associated plants as well as the soil composition, moisture, and number of nutrient in the soil (Smith, 2000). Bonfirm et al., (2016) provideevidence the diversity of Arbuscular Mycorrhizal Fungi in a Brazilian Atlantic Forest. Similarly Renuka (2012) reported a seasonal dependency of mycorrhiza in tropical regions.

Cashew nut (A. occidentale $\mathrm{L})$ is one of the important crops in arid regions, reaching a productivity of 42 ton / ha (Witjaksono et al., 2002). This leads to an income of the farmers up to 543.000 US\$ in a year (Biro Pusat Statistik, 2002). Beside cashew nuts, only few crops can be cultivated on these soils, leading very often to monoculture. In Indonesia, the cashew nut plant has been planted through the government for reforestation program especially in Bali, Sulawesi, Central of Java in Indonesia, because it is and well adapted to dry areas and growing well in these regions. Now-days, the cashew nut plant is one of the main sources of income for the local communities.

The cashew nut has been introduced to Bali in 1976 (Antara, 2004), and especially promoted during 1990 through the Governmental of Bali Province program. The arid regions in Bali Island are mostly in the Northern Bali region i.e. Western of Buleleng Suburb (i.e. Gerokgak region) and Western of Karangasem Suburb (i.e. Sukadana region). These areas are dominated by plant communities adapted to the dry regions, such as Cassava and Cashew nut Plants (Antara, 2004; Daryana, 2010; Proborini, 2011).

Balinese cashew nuts have been demonstrated to mutualize with 13 species of mycorriza by Proborini et al., (2013). It is most likely that the good performance of Cashew nut plants in Bali depend on this symbiosis. So far, no studies on the special and regional distribution of the different mycorriza species in Bali have been carried out. This study analyses the occurrence of mycorriza communities associated with cashew nut plants over two different areas in the arid region of Bali, during the dry and rainy season.

\section{Materials and Methods}

\section{Soil and plant root sampling}

Soil and plant sample were taken from western of Karangasem Suburb (i.e. Sukadana region and Western of Buleleng (i.e. Gerokgak region). The regions are known as cashew nut plantation area. Sampling of soil and Cashew nut plant root were 2 monthly intervals from cashew nut plantation area from April of 2011 up to February 2012. Soil sampling method was adapted from Widiastuti (2004). The soil was taken from rizhospere soil at surrounded of cashew plant root $\pm 20-30 \mathrm{~cm}$ depth. Two composite sample bags (@Ca 2 kg) per site were collected from five sampling sites randomly chosen (totally 20 bags per sampling period).

Sample of root was tertiary root of young cashew nut plant (plant height $c a 40 \mathrm{~cm}$ ). Five individual plant of cashew nut were sampled from each sampling region (totally 10 individual of cashew nut plant per sampling period).

\section{Percentage of plant root colonization}

Percentage of plant root colonization was calculated by means of the method of Kormanik and Mc.Graw (1982) modified (Proborini, 1998). Plant roots sample were processed i.e. clearing, staining and destaining consecutively. The observation of VAM colonization in root cortex and endomycorrhizal hifa was carried out by means of dissecting-set and binocular microscopes. To count the percentage of mycorrrhizal colonization by using formula is as below:

$\%$ root colonization $=\frac{\sum \text { Vertical cross }+ \text { horizontal cross hypha }}{\text { Total root length examined }}$

\section{Isolation and spore density}

The spore isolation from rizhosphere soil was carried out by the means of the method of Brundrett et al., (2008) i.e. wet decantation method. Soil sample i.e. 250 gram soaked in 1 L of water (ratio of water: soil is 1:4) and steered. The supernatant was decanted in five consecutive sieves (AnalysensiebEckhardt 5657 Haan W. Germany) with top down mesh size $500 \mu \mathrm{m}, 300 \mu \mathrm{m}$, 
$200 \mu \mathrm{m}, 63 \mu \mathrm{mdan} 45 \mu \mathrm{m}$ consecutively. The spores found were observed under dissecting microscope. The total number of spore was counted and the spore was fixed in a glass bottle filled containing sterilized water.

\section{Physical and chemical properties of soil}

Soil was collected from cashew nut plantation area at either Sukadanaregion-Karangasem Suburb or Gerokgak region-Buleleng Suburb. Five bags of rizhosphere soil (@ $2 \mathrm{~kg}$ ) were composite per sampling period. Soil sample was 2 monthly interval sampled over exploration study. The physico-chemical of soil properties were analysed at the Laboratory of Soil, Faculty of Agriculture University of Udayana and Technical Service of Analytical Laboratory University of Udayana.

\section{Rain fall Frequency and rain water level}

The data of rain fall frequency and the rain water level was obtained from BMKG Bali Regional. The data collected was for one year period i.e. April 2011 up to April 2012.

\section{Results and Discussion}

\section{Rain fall frequency and rain water level}

A data of rain fall frequency and rain water level over one year period (January 2011 up to February 2012) at both regions is presented at Figure 1 and 2. Though raining season seems longer at Sukadana region than at Gerokgak region, the data showed clearly similar temporal dynamic at both regions. Raining season occurs at April up to June and December up to February; Dry season is at June up to December.

\section{Physico-chemical soil properties}

The status of spatial and temporal of physico-chemical soil properties is presented at Table 1 and 2. The data showed clearly that, except K level, soil water level, C, $\mathrm{N}$ and $\mathrm{P}$ are higher at Gerokgak region than those at Sukadana region. These data depicts the soil status of Gerokgak region is overall better than those of Sukadana region. The soil water level at both regions fix to either the dynamic of rain fall frequency or rain water level. The soil water level of Sukadana region is lower than those of Gerokgak region, it likely related to the soil texture. Sandy soil textures tend to have lesser capacity to retain water than clay soil texture, because sandy soil has more pores than clay soil. High soil pores could also lead to high soil nutrients wash $(\mathrm{C}, \mathrm{N}$ and $\mathrm{P})$ at sandy soil compare to clay soil texture. Though some of the physico-chemical soil properties show difference spatially, overall Sukadana and Gerokgak regions could be classified as arid regions, leading to the conclusion that $A$. occidentalle plant at the regions is highly rely on to mutual symbiosis with VAM.

\section{Endomycorrhizal spores density}

A total of 120 sample bags were examined. Direct microscopic counting showed massive number of VAM spores at the regions over sampling period is presented at Figure 3. The spore density showed convincingly variation either spatially or temporally (Fig. 3).

Spatially, the spore density in the rizhospere of cashew nut plant (A. occidentale L) sampled from Sukadana region showed consistently more abundant than those sampled from Gerokgak region. Take account to the soil physico-chemical properties, such spore density variation confirm to the spatial variation of the soil properties i.e. texture, nutrient and water level (Table 1 and 2). Soil Water level is likely to be the most determinant factor affecting such spatial variation of spore density, water stimulates spore to germinate. There-fore spore density tends to decrease during rainy season because the spore will germinate to form hypha (Smith, 2000, Delvian, $2006 \mathrm{~b}$ ). This study found that level of Phosphorous (P) and $\mathrm{N}$ level seem positive linear to the spore density. This is in-contrast to Khumar et al., (2016) who showed negative linear of phosphorous availability and spore density. While, the finding on $\mathrm{N}$ level - spore density correlation agrees to the study of Gobharani et al., (2012) and Sawant and Bhale (2016) who showed the VAM spore density supported by higher available $\mathrm{N}$ in soil. However, this finding does not fit to the study of Khumar et al., (2016) who revealed that $\mathrm{N}$ soil content do not have any influence on spore density. The spore density is found high at Sukadana region having high pores soil texture i.e. sandy clay. This is in contrast to the study Okiobe et al., (2015) who showed Clay-sand mixture (2: 1) to have more spore density. Nevertheless, soil pore is likely to exert positive role on VAM spore formation.

Temporally, the dynamic of spore density at both regions are clearly fixed to the temporal dynamic of rain fall frequency and water level. The figure showed opposite trend between spore density and the rain fall frequency and water level, the spore number tend to increase when rain fall frequency and water level decrease (June up to December) and vice versa (April up to June and 
December up to February). Spore is resulted by hypha of Mycorizhal fungi and spore formation is one of the mechanisms of self-defense when environmental condition does not support the development of hypha. This finding fit to Smith (2000) and Delvian (2006 b), the existence of endomycorrhiza spore in the nature is season related, the spore number tends to decrease during rainy season because the spore will germinate to form hypha and the hypha will grow to find out soil or supply water over dry season.

Fig.1 Graphic of rain fall frequency and average of water level at Sukadana region

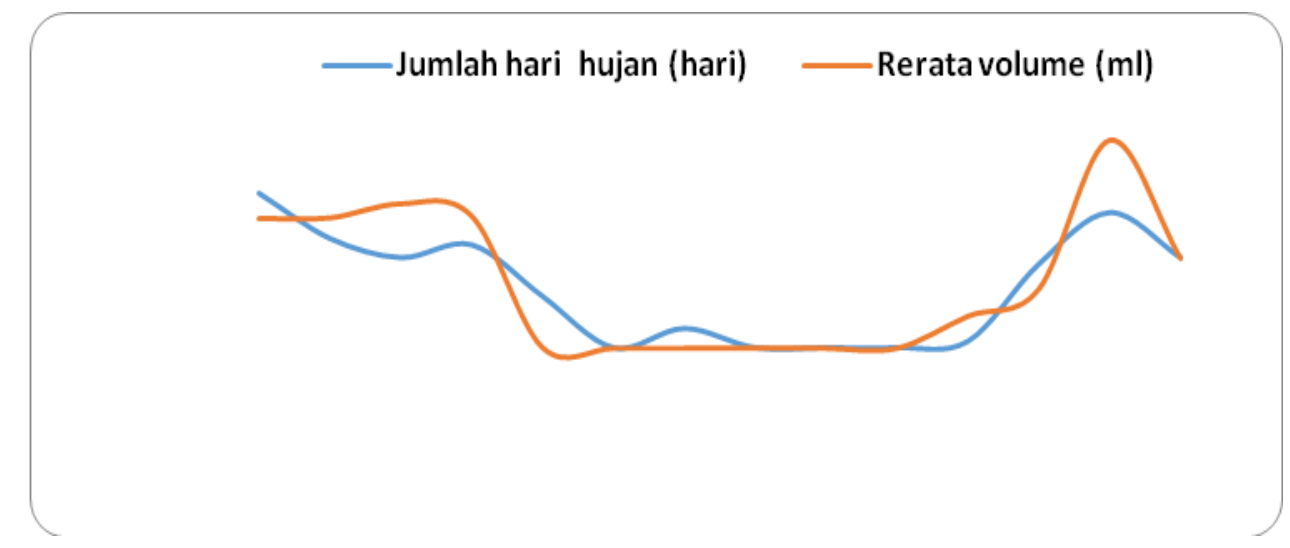

Fig.2 Graphic of rain fall frequency and average of water level at Gerogak region

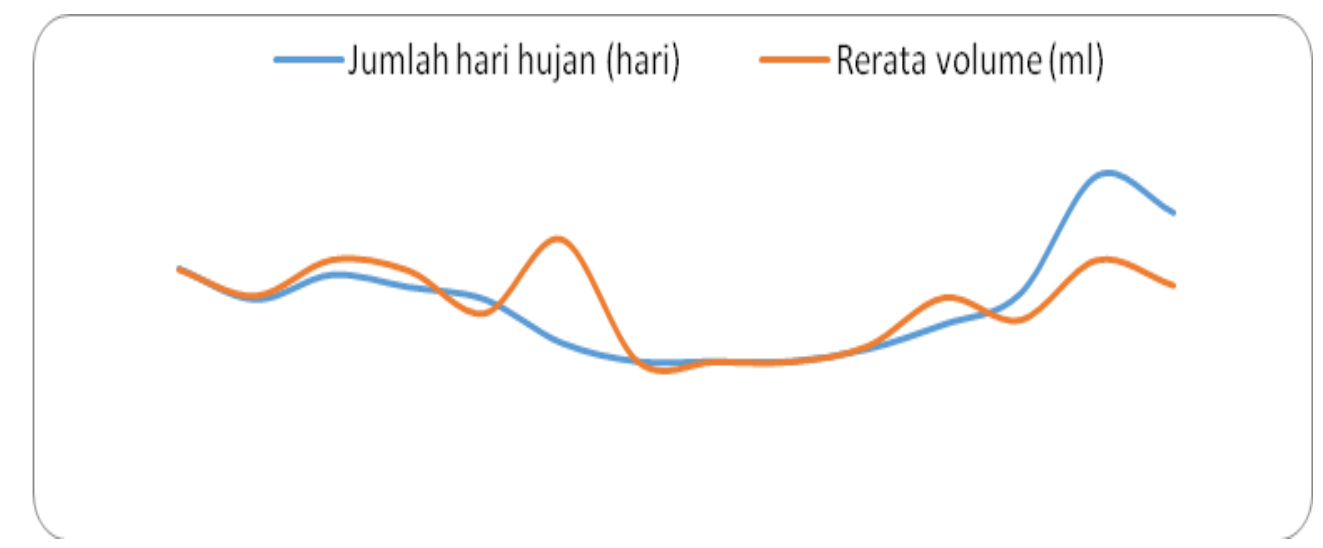

Fig.3 Temporal and spatial of spore density in rizhosphere of Cashew plants

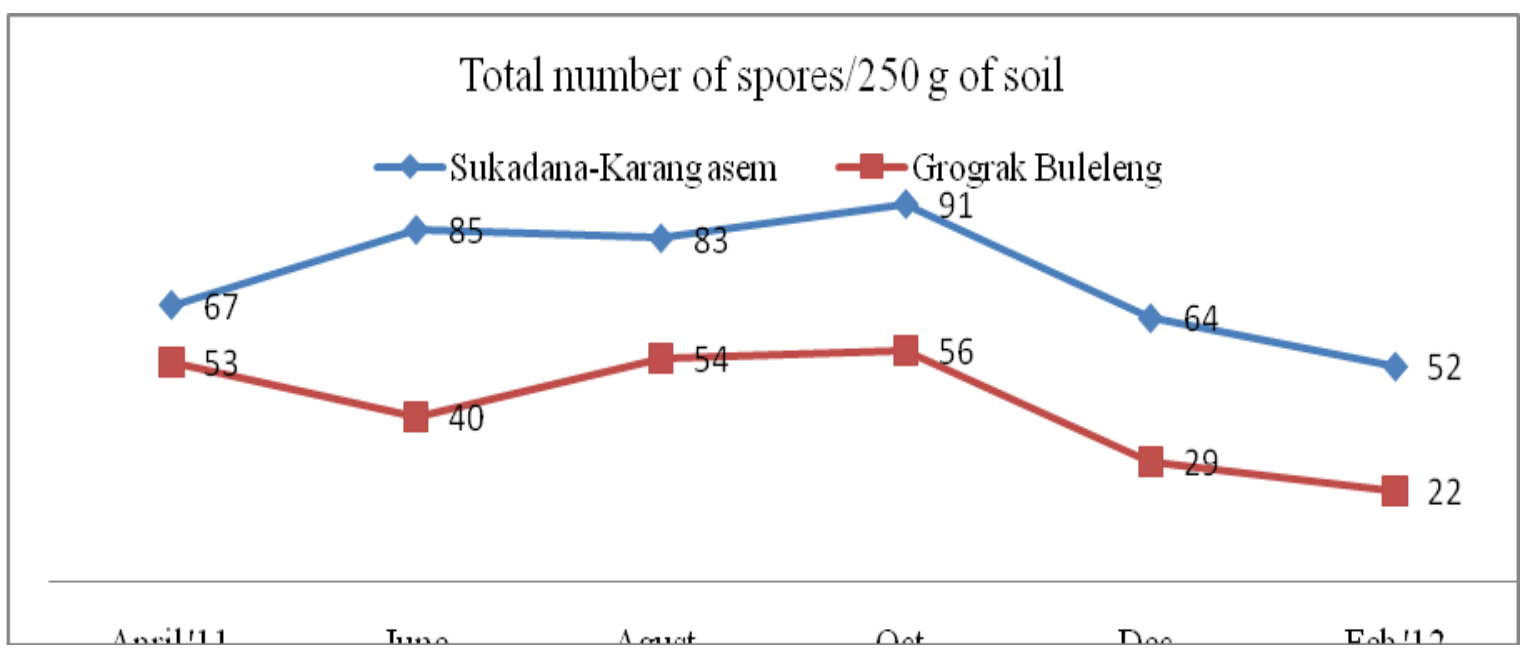


Fig.4 Spatial and temporal variation of average percentage of endomycorrhiza

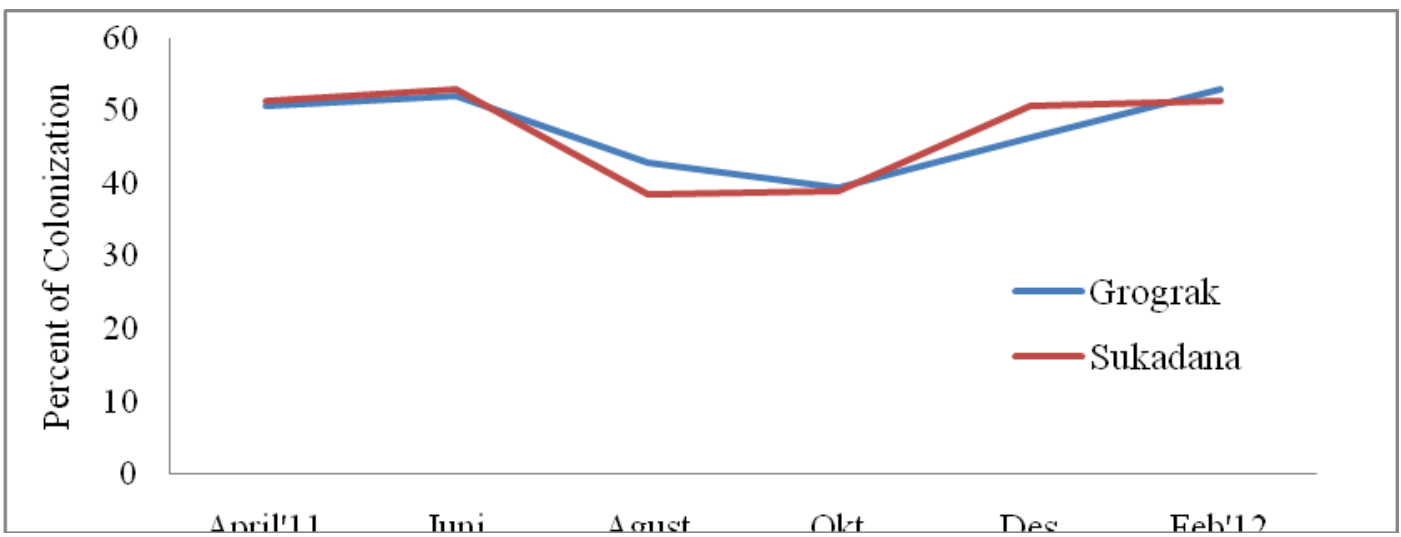

Fig.5 AMF colonization in the root (Binoculer microscope 100x) (Proborini, 2013)

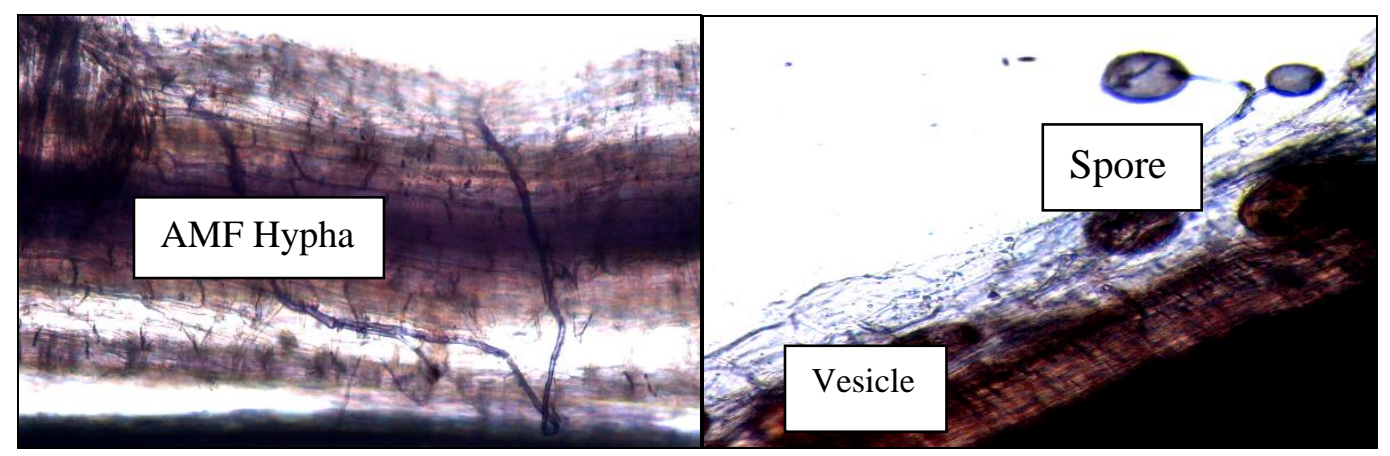

Table.1 the analysis of nutrients on the soil from Gerogak and Sukadana region

\begin{tabular}{|c|c|c|c|c|c|c|c|c|c|c|}
\hline \multicolumn{6}{|c|}{ Grograk-Buleleng } & \multicolumn{5}{|c|}{ Sukadana-Karangasem } \\
\hline & pH & $\begin{array}{l}\text { C-organic } \\
(\%)\end{array}$ & $\begin{array}{l}\text { Total N } \\
(\%)\end{array}$ & $\begin{array}{l}\text { K-available } \\
\text { (ppm) }\end{array}$ & $\begin{array}{l}\text { P-available } \\
\text { (ppm) }\end{array}$ & pH & $\begin{array}{l}\text { C-organic } \\
(\%)\end{array}$ & $\begin{array}{l}\text { Total N } \\
(\%)\end{array}$ & $\begin{array}{l}\text { K-available } \\
\text { (ppm) }\end{array}$ & $\begin{array}{l}\text { P-available } \\
\text { (ppm) }\end{array}$ \\
\hline April'11 & $6,1(\mathrm{SA})$ & $0,79(\mathrm{VL})$ & $0,05(\mathrm{VL})$ & $79,65(\mathrm{VH})$ & $53,54(\mathrm{VL})$ & $6,8(N)$ & $1,28(\mathrm{~L})$ & $0,12(L)$ & $61,60(\mathrm{VH})$ & $662,07(\mathrm{VH})$ \\
\hline June & $6,8(N)$ & $0,78(\mathrm{VL})$ & $0,06(V L)$ & $102,25(\mathrm{VH})$ & $87,44(L)$ & $6,8(N)$ & $1,26(\mathrm{~L})$ & $0,18(L)$ & $48,85(\mathrm{VH})$ & $665,22(\mathrm{VH})$ \\
\hline August & $6,7(N)$ & $0,79(\mathrm{VL})$ & $0,05(\mathrm{VR})$ & $64,10(\mathrm{VH})$ & $51,34(\mathrm{VL})$ & $6,9(N)$ & $0,70(\mathrm{VL})$ & $0,16(L)$ & $69,04(\mathrm{VH})$ & $774,11(\mathrm{VH})$ \\
\hline Oct & $6,9(N)$ & $0,78(V L)$ & $0,13(L)$ & $111,51(\mathrm{VH})$ & $54,24(V L)$ & $6,5(N)$ & $0,42(V L)$ & $0,15(L)$ & $68,10(\mathrm{VH})$ & $525,26(\mathrm{VH})$ \\
\hline Dec & $6,5(\mathrm{~N})$ & $0,69(\mathrm{VL})$ & $0,08(V L)$ & $98,67(\mathrm{VH})$ & $56,67(\mathrm{VL})$ & $6,2(\mathrm{SA})$ & $0,52(V L)$ & $0,13(L)$ & $66,67(\mathrm{VH})$ & $520,21(\mathrm{VH})$ \\
\hline Feb'12 & $6,3(\mathrm{SA})$ & $0,66(V L)$ & $0,07(V L)$ & $92,46(\mathrm{VH})$ & $54,46(V L)$ & $6,7(N)$ & $1,25(\mathrm{~L})$ & $0,10(L)$ & $63,42(\mathrm{VH})$ & $512,34(\mathrm{VH})$ \\
\hline
\end{tabular}

Table. 2 The analysis of water content and soil texture from Sukadana and Gerogak region

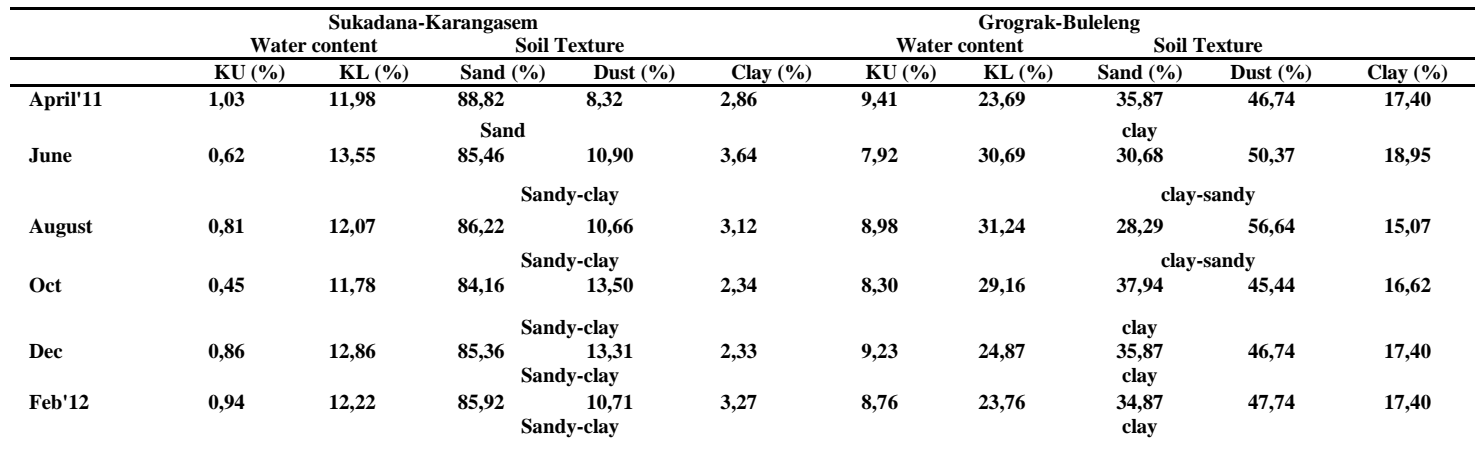




\section{Percentage of root colonization}

A total of 120 individual samples examined showed clearly the colonization of VAM in the root of cashew nut plant (Figure 5). The average percentage of endomycorrhizal colonization in the samples from both sampling regions is presented at Figure 4. The root colonization showed convincingly temporal dynamic but not spatially (Fig. 4).

This study, based on spatial observation of vesicle, arbuscule and mycelia in $A$. occidentalle root, the root colonization at both regions varries from $38.38 \%$ up to 52.94. This finding confirms the high level symbiosis between VAM and A. occidentalle at the regions. The finding of this study also showed that despite difference in soil properties in the regions studied, no significant difference in root colonisation. High root colonisation at Gerokgak region can be addressed to the low of Phosphorous availability. One adaptation of plant to low Phosphorous availability is symbiosis with VAM, the fungi re-mineralizes Phosphorous and delivers Phosphate (P) and other minerals in exchange for carbohydrate (Smith et al., 2010). Though Phosphat (P) availability is very high at Skadana region that could supress the VAM colonisation, it is likely that the low level of $\mathrm{N}$ overruled Phosphat supressive (Carbonnel and Gutjahr, 2014).

The result of temporal dynamic of root colonisation showed similar trend at Sukadana and Gerokgak regions, the trend fits to the dynamic of rail fall frequency and rain water level. The root colonisation tend to high over raining season(April up to June 20111 and December up to February 2012) and decrease gradually over dry season (june up to December 2011).

This dynamic of root colonisation is likely related to again soil water level, water stimulate VAM spore to germinate and form hypha that immediately colonize plant root (Chalimah et al., 2007). The result also agrees with Delvian (2006b) dan Smith et al., (2010), hypha colonization is season related. Such colonization facilitate endomycorrhyza gets benefit from the host plant i.e. glucose (Hapsoh, 2008). While the host plant gets some benefits from endomycorrhiza colonization i.e. the endomycorrhiza takes a role on re-mineralization of Phosphorous and providing Phosphate $(\mathrm{P})$ in soil (Smith et al., 2010), on water absorption and mineral uptake (Renuka et al., 2012) and on producing plant growth hormone-like similar to auxin, cytokine and Gyberelin (Imas et al., 1989).
Recall all explanation above, it can be concluded that $A$. acidentalle at Sukadana and Gerokgak regions have mutual symbiosis with VAM fungi. Nevertheless, in accordance with soil properties difference, the VAM seems to take role on water supply and soil mineral delivery (i.e. N) at Sukadana region and to take a role on soil minerals delivery (i.e. $\mathrm{N}$ and $\mathrm{P}$ ) at Gerokgak region.

\section{Acknowledgments and legal responsibility}

Thanks to Directorate General of Research Technology, Ministry of Education and Culture of Republic Indonesia and the LPPM of University of Udayana Bali (grant of Hibah Bersaing scheme, 2014) for providing financial support and extending essential facilities to carry out this research work.

\section{References}

Aditya, 2011. Kondisi fisik Kabupaten buleleng. Portal on line Buleleng. http://www.bule lengkab.go.id/profil-daerah/979-i-kondisi-fisikkabupaten-buleleng.

Al-Zalzaleh, Hani, A. Majid, Anu Ray Mathew, 2009. VAM Inoculation for Selected Ornamental Plants in Bioremediated and Agricultural Soils. European Journal of Scientific Research. 25(4).559-566.

Andhra Pradesh, India. ASIAN J. EXP. BIOL. SCI. 3(1):228-235

Antara, M. 2004. Pendekatan Agribisnis dalam Pengembangan Pertanian Lahan Kering. Makalah Seminar Pengelolaan LahanLahan Kering Beririgasi Berkelanjutan yang Berorientasi Agribisnis. Singaraja. 5. Feb 2004.

Bever, J.D., Morton, J.B., Antonovics, J. and Schultz, P.A. (1996). Host-dependent sporulation and species diversity of arbuscular mycorrhizal fungi in a mown grassland. Journal of Ecology 84: 71-82.

Biro Pusat Statistik. 2002. Sulawesi Tenggara dalamAngka. Badan Pusat Statistik Provinsi Sulawesi Tenggara.

Bohrer, K.E. dan Amon, J.P. (2004). Seasonal dynamis of Arbuscular Mycorrhizal fungi in differing wetland habitats. Mycorrhiza. 14 :329-337.

Bonfim, JA, Vasconcellos RL, Gumiere T, de Lourdes Colombo Mescolotti D, Oehl F, Nogueira Cardoso EJ. Diversity of Arbuscular Mycorrhizal fungi in a Brazilian Atlantic Forest Toposequence. Microbial Ecology. 71(1):164-77. doi: 10.1007/s00248-0150661-0. 
Brundrett, M., N. Bougher, B. Dell,. T. Grove, dan N. Malajczuk. 2008. Working with Mycorrhizas in Forestry and Agriculture. ACIAR Monograph 32. Australian Centre for International Agricultural Research, Canberra.

Carbonnel, S and C. Gutjahr. 2014. Control of Arbuscular Mycorrhiza development by nutrient signal. Plant Science. Doi: 10.3389/fpls.2014.00462.

Daryana, P. 2010. Padi Gogo di Kecamatan Gerogak. Dinas komunikasi dan Informasi. http://kominfo.bulelengkab. go.id/index. php? option $=$ com_contentdanview $=$ articledanid $=80$ :padi gogo-di-kecamatan-gerokgakdancatid=46: majalahsinga-manggaladanItemid $=83$ opened at 2 Februari 2011

Deacon,J,W. 1997. Modern Mycology. Third edition. Blackwell Science Ltd. Oxford.

Delvian, 2006b. Dinamika Sporulasi Cendawan Mikoriza Arbuskula. Departemenke hutanan Fakultas Pertanian Universitas Sumatra Utara. Medan

Delvian. 2003. Keanekara gamancen dawanmik orizaarbuskula (CMA) di hutanpantaidan potensipeman faatannya (Studikasus di hutancagaralam Leuweung Sancang Kabupaten Garut, Jawa Barat). [disertasi]. Bogor: Program Pascasarjana, InstitutPertanian Bogor.

Geeta S.V., K. shrestha, B. Khadge, Nancy C. Johnson. and H. Wallander. 2007. Study of biodiversity of arbuscular mycorrhizal fungi in addition with different organic matter in Different seasons of kavre district (central Nepal). Scientific world, 5 (5).221-227

Ghorbani, M., J. Khara and N. Abbaspour. 2012Vesicular-Arbuscular Mycorrhizal Symbioses in some plant and tehir relationship with soil factors and seasons. Iranian Journal of Plant Physiology 3 (1),589- 594 .

Husna, Budi SW, Mansur I, Kusuma DC. 2015. Diversity of Arbuscular Mycorrhizal Fungi in the Growth Habitat of Kayu Kuku (Pericopsis mooniana Thw.) In Southeast Sulawesi. Pakistan Journal Biological Sciences. Jan;18(1):1-10

Idwardan Ali M.2000. Pengaruh Mikoriza Vesikular Arbusklarterhadap Keefisienan Penggunaan Pupuk P oleh Tanaman Jagung (Zea mays L.).Jurnal Natur Indonesia II (2): 168-178.

Imas T., Hadioetomo, A.W. Gunawan, Y. Setiadi, 1989. Mikrobiologi tanah II. Departemen pendidikan dan kebudayaan. Direktorat Jenderal Pendidikan Tinggi. PAU. ITB. 145 hal.
Johnson,N.C., J.H. Graham and F.A. Smith. 1997. Functioning of mycorrhizal associations along the mutualism-parasitism continuum. New Phytol 135.575-585.

Kumar, V., R. Kumar, A. Kumar, and D. Anal. 2016. Spore population, colonization, species diversity and factors influencing the association of arbuscular mycorrhizal fungi with litchi trees in India. J. of Env. Biology. 37:91-100

Okiobe, S.T., M. A. Angue, B.P. Bougnom, B. Onana and D. Nwaga. 2015. Improvement of Arbuscular Mycorrhizal Fungi inoculum production by nutrient solution concentration and soil texture variation. International Journal of Agronomy and Agricultural Research (IJAAR). 6(5).7-20

Proborini, M. W. 1998. Spatial and Temporal distribution of VA Mycorrhizal Fungi in Tasmanian Heathland. (thesis). University of Tasmania. Hobart. Australia.

Proborini, M. W., M. Sudana, W. Suarna, Pt. Ristiati. 2013. Indigenous Vesicular Arbuscular Mycorrhizal (VAM) Fungi in Cashew nut (Anacardiumoc cidentale L.) Plantation of North East bali IslandIndonesia. Journal of Biology, Agriculture and Healthcare. 3 (3) 114 -121.

Proborini. M.W., 2011. The Preliminary Spatial Study OfEndomycorrhizal Fungi In Root-Plants Of Dried Areas In Buleleng, Bali. ISSAAS International Congress 2010 "Agricultural Adaptation in Response to Climate Change" 14-18 November 2010. J ISSAAS Vol. 17, No. 1: 227-273 (2011)

Renuka, G. M.S. Rao, M. Ramesh, V. Praveen Kumar and S. Ram Reddy. 2012. Distribution and Diversity of AM Fungal Flora in Godavari Belt Forests,

Sawant, V.S. and U.N. Bhale. 2016. Physico-chemical Analyses and Status of Arbuscular Mycorrhizal Fungi from Rhizosphere Soils of Solanaceous Vegetables. IOSR J. Pharmacy and Bio. Sci (IOSRJPBS). 11 (6): 97-104.

Smith, F. A. 2000. Measuring the influence of mycorrhizas. New Phytology. 148:4-6.

Smith, S.E. and D.J. Read. 1997. Mycorrhizal Symbiosis. ( $2^{\text {nd }}$ edition). Academic Press, London. 605pp.

Smith, S.E.; E. Facelli; S. Pope; F.A. Smith. 2010. Plant Performance in stressful environment: interpreting new and established knowledge of the roles of arbuscular mycorrizhas. Plant Soil 326:3-20.

Widiastuti H. 2004. BiologiInteraksi Cendawan mikoriza Arbuskula Kelapa Sawitpada Tanah Masamsebagaidasr Pengembanganteknologi Aplikasi Dini. (ringkasan disertasi). Sekolah PascaSarjana. Institut Pertanian Bogor. 
Widiastuti H. Edi Guhardja, Nampiah Soekarno, L. K. Darusman, DidiekHadjar Goenadidan Sally Smith. 2002. Optimasi simbiosis cendawan mikoriza arbuskula Acaulospora tuberculata dan Gigaspora margarita pada bibit kelapa sawit di tanahmasam. Menara Perkebunan.70:2:50-57.
Witjaksono, Y., ahmadsulle dansubaedahruku. 2002. Strategi Akselerasi Peningkatan Pendapatan Petani Jambu Mete di Sulawesi Tenggara. Balai Pengkajian Teknologi Pertanian Sulawesi Tenggara.

\section{How to cite this article:}

Meitini Wahyuni Proborini, Deny Suhernawan Yusup, Yan Ramona and Ni Putu Ristiati. 2017. Spatial and Seasonal Distribution of Endomycorrhiza from Cashew Nut in Bali. Int.J.Curr.Res.Aca.Rev. 5(10), 34-41.

doi: https://doi.org/10.20546/ijcrar.2017.510.006 